\title{
Nitrogen Balance and Body Weight Change of Adult Roosters Fed Single Essential Amino Acid Devoid Diets
}

\author{
Jun-ichi Okumura ${ }^{1)}$, Yoshio NaKahiro ${ }^{2)}$ and Katsutoshi Kino ${ }^{1)}$
}

1) Laboratory of Animal Nutrition, Faculty of Agriculture, Nagoya University, Nagoya-shi 464

2) Faculty of Agriculture, Kagawa University, Kagawa-ken 761-07

BLOCK and MiTCHELL ${ }^{1)}$ showed a reasonably high correlation between biological value and calculated percentage deficit of the most limiting amino acid with several dietary proteins in rats. From their observation it has been generally accepted that nutritive quality of dietary protein is determined by the most limiting essential amino acid. Ashida and Yoshida ${ }^{2)}$, however, noted that the effect of the deficiencies of various single essential amino acids on nitrogen balance of adult rats was differed even when the percentage deficiencies of these amino acids for the maintenance requirement were the same. They suggested that there was the nutritional specificity of essential amino acids in the effects of deficiency.

In chickens, there are some reports which suggested the existence of the specificity of essential amino acid to maintain nitrogen balance. LEvEILLE and FISHER ${ }^{3)}$ reported adult roosters were not in negative nitrogen balance even in the complete absence of lysine from the diet. Ishibashi ${ }^{4}$ ) showed that adult roosters fed a diet in which phenylalanine was completely replaced by tyrosine maintained nitrogen equilibrium for 1 year.

In the present study, to demonstrate the existence of comparative nutritional specificity of essential amino acid in chickens the effect of deprivation of single essential amino acid from a well-balanced amino acid diet on nitrogen balance and body weight change in adult roosters was investigated.

\section{Materials and Methods}

Single comb, White Leghorn adult roosters weighing about 1460 to $2040 \mathrm{~g}$ were used. At the start of the experiments, roosters were individually weighed and were then selected and assigned to 9 groups of 6 birds (experiment 1) or 5 groups of 6 birds (experiment 2) in such a way that the body weight distribution was uniform for each group. They were kept in individual metabolism cages and given appropriate experimental diets for 7 days. On days 3 , 5 and 7 body weight was measured. Excreta was collected for the last 3 days of the experimental period and total nitrogen in the excreta was determined by a Kjeldahl method. Nitrogen balance was calculated by subtracting nitrogen in the excreta from nitrogen consumed.

Table 1 shows the composition of a complete diet which contains all essential amino acids at their requirement levels (ISHIBASHI $\left.{ }^{4}\right)$. Diets used in the experiment 1 were 8 single essential amino acids (histidine, lysine, arginine, threonine, isoleucine, tryptophan, 
Table 1. Composition $(\mathrm{g} / \mathrm{kg})$ of complete diet

\begin{tabular}{|c|c|c|}
\hline & Amino acid mixture ${ }^{1}$ & 57.9 \\
\hline & Vitamin mixture ${ }^{2}$ & 2.0 \\
\hline & Mineral mixture ${ }^{3}$ & 56.3 \\
\hline & Choline chloride & 1.5 \\
\hline & Corn oil & 30.0 \\
\hline & Cellulose & 30.0 \\
\hline & Sucrose & 200.0 \\
\hline & Corn starch & to 1,000 \\
\hline 1 & \multicolumn{2}{|c|}{$\begin{array}{l}\text { Contained } 1.33 \mathrm{~g} \mathrm{~L} \text {-Arginine } \cdot \mathrm{HCl}, 0.33 \mathrm{~g} \text { L-Histidine- } \\
\mathrm{HCl}, 2.00 \mathrm{~g} \text { L-Lysine } \cdot \mathrm{HCl}, 0.17 \mathrm{~g} \mathrm{~L}-\text { Tryptophan, } 0.67 \\
\mathrm{~g} \mathrm{~L}-\text { Phenylalanine, } 0.67 \mathrm{~g} \mathrm{~L} \text {-Threonine, } 0.67 \mathrm{~g} \mathrm{~L} \text { - } \\
\text { Leucine, } 1.33 \mathrm{~g} \mathrm{~L}-\text { Isoleucine, } 1.33 \mathrm{~g} \mathrm{L-Valine,} 1.67 \mathrm{~g} \\
\text { L-Methionine, } 6.67 \mathrm{~g} \text { Glycine and } 41.08 \mathrm{~g} \mathrm{L-Glutamic} \\
\text { acid. }\end{array}$} \\
\hline 2 & \multicolumn{2}{|c|}{ OKUMURA et $a l .5$} \\
\hline 3 & \multicolumn{2}{|l|}{ NeSHEIM $\left.\boldsymbol{e} t \boldsymbol{a l} \cdot{ }^{6}\right)$} \\
\hline
\end{tabular}

glycine and methionine) devoid diets and an amino acid-free diet. In the experiment 2 , phenylalanine-, leucine-, methionine- and amino acid-free diets were used as experimental diets. Glutamic acid was substituted isonitrogenously for deprived amino acids in the deficient diets. The birds consumed these diets at the rate of $30 \mathrm{~g} / \mathrm{kg}$ body weight/day and this allotment supplied sufficient amounts of nitrogen $(197 \mathrm{mg} / \mathrm{kg}$ ) and energy (105 kcal metabolizable energy $/ \mathrm{kg}$ ) to maintain nitrogen equilibrium in the adult rooster (ISHIBASHI $\left.{ }^{4}\right)$. Water was given ad libitum.

Analysis of variance was used to analyze the data statistically and for comparisons of the individual treatment differences, the Duncan's multiple range test $\left(\operatorname{DunCAN}^{7)}\right)$ was applied.

\section{Results and Discussion}

Table 2 gives nitrogen balance and body weight change of the roosters fed single essential amino acid deprived diets. Nitrogen balance of roosters were different depending upon the amino acid which deprived from diets. In experiment 1 , the roosters receiving the lysine-free diet showed the least nitrogen loss, and feeding the methionine-free diet resulted in the severest nitrogen loss. In experiment 2 the effect of leucine or phenylalanine deficiency on nitrogen balance was significantly less compared with that of methionine deficiency. IsHIBASH ${ }^{8)}$ studied amino acid requirement for maintenance of adult roosters and reported roosters fed histidine- or phenylalanine-free diet could maintain nitrogen equilibrium. Positive nitrogen balance of adult roosters fed phenylalanine-free diet was also reported by Ishibashi and KametaKa ${ }^{9}$. Leveille and Fisher ${ }^{3)}$ observed that adult roosters receiving lysine- or histidine-devoid diet were in positive nitrogen balance. In the present study roosters fed histidine-, lysine- and phenylalanine-free diets showed negative nitrogen balance, however, they belong to the least negative nitrogen balance group.

Nitrogen balance of the roosters fed the methionine-free diet was the lowest and worse than that of the birds fed an amino acid-free diet. From the results it can be postulated that when roosters were fed an all amino acid deprived diet, methionine would be the most 
Table 2. Effect of single essential amino acid deprivation on nitrogen balance and body weight change in adult roosters

\begin{tabular}{|c|c|c|}
\hline \multicolumn{3}{|l|}{ Experiment 1} \\
\hline $\begin{array}{l}\text { Deprived } \\
\text { amino acid }\end{array}$ & $\begin{array}{l}\text { Nitrogen balance } \\
(\mathrm{mg} / \text { day })\end{array}$ & $\begin{array}{l}\text { Body weight change } \\
\text { ( } \mathrm{g} / 7 \text { days })\end{array}$ \\
\hline Lys & $-188^{a}$ & $-36.0^{\mathrm{a}}$ \\
\hline Trp & $-193^{a}$ & $-64.7^{\mathrm{abc}}$ \\
\hline His & $-215^{a}$ & $-27.7^{\mathrm{a}}$ \\
\hline Gly & $-232^{a}$ & $-79.0^{a b c}$ \\
\hline Ile & $-304^{b}$ & $-63.5^{a b c}$ \\
\hline Thr & $-345^{b c}$ & $-57.8^{\mathrm{ab}}$ \\
\hline Arg & $-367^{b c}$ & $-67.3^{\mathrm{abc}}$ \\
\hline All & $-406^{c}$ & $-106.0^{b c}$ \\
\hline Met & $-488^{\mathrm{d}}$ & $-114.7^{\mathrm{c}}$ \\
\hline Pooled SEM & 24.7 & 16.5 \\
\hline \multicolumn{3}{|l|}{ Experiment 2} \\
\hline $\begin{array}{l}\text { Deprived } \\
\text { amino acid }\end{array}$ & $\begin{array}{l}\text { Nitrogen balance } \\
(\mathrm{mg} / \text { day })\end{array}$ & $\begin{array}{c}\text { Body weight change } \\
\text { ( } \mathrm{g} / 7 \text { days })\end{array}$ \\
\hline Leu & $-238^{a}$ & $-58.7^{\mathrm{a}}$ \\
\hline Phe & $-261^{a}$ & $-64.7^{\mathrm{ab}}$ \\
\hline All & $-402^{\mathrm{b}}$ & $-113.7^{b}$ \\
\hline Met & $-485^{b}$ & $-101.7^{a b}$ \\
\hline Pooled SEM & 31.7 & 17.2 \\
\hline
\end{tabular}

Values are means of 6 birds. Means with unlike superscripts in the same column are significantly different $(\mathrm{P}<0.05)$.

limiting amind acid. Okumura and Muramatsu ${ }^{10)}$ found that supplementation of methionine improved nitrogen balance of chicks fed a protein-free diet. Such phenomenon of methionine in rats has been reported. AsHIDA and Yoshida ${ }^{2)}$ showed rats fed a protein-free or methionine-free diet were in a similar negative nitrogen balance. YoкоGoshi and YoshidA ${ }^{11}$ ) reported the nitrogen-sparing action of supplemented methionine in rats fed a protein-free diet. These reports suggest that methionine is the most limitting amino acid in protein depleted conditions.

Figure 1 shows body weight change of roosters fed the single essential amino acid deprived diets. On day 3 body weight change of the roosters already varied depending upon the deficient amino acid and thereafter the roosters lost their body weight continually and the difference in body weight change between dietary groups became remarkable in both experiments. Similarly to the result of nitrogen balance, body weight loss of roosters fed the histidine- or lysine-free diet was the least and that of birds fed the methiodine-free diet was the most. In a series of studies investigating the maintenance requirement of an essential amino acid for adult roosters, Leveille and Fisher ${ }^{3,12)}$ and Leveille et al. ${ }^{13)}$ reported that birds fed a histidine- or lysine-free diet could maintain their body weight while the birds fed other essential amino acid-free diets showed negative change in body weight. OUSTERHOUT ${ }^{14}$ investigated survival time and biochemical changes in chicks fed diets devoid of different essential amino acids and indicated that chicks fed diets lacking histidine or lysine lost weight 

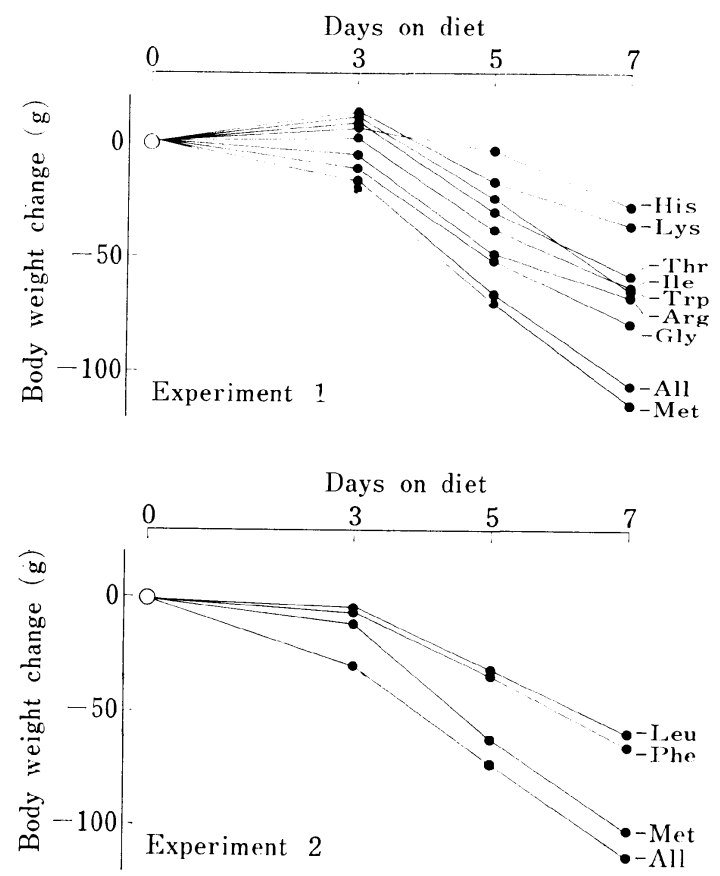

Fig. 1. Body weight change of adult roosters fed single essential amino acid deprived diets.

slower and survived longer compared with the other deficient groups. SAID and HEGSTED ${ }^{15}$ ) observed that adult female rats fed a diet free of methionine plus cystine responded in a similar manner to rats fed a protein-free diet, whereas rats fed a lysine- or leucine-free diet lost less tissue than rats fed a protein-free diet did. The results of the present experiment are in line with those of above workers ${ }^{3,12,13,14,15)}$ who showed that histidine- or lysine-deficiency and methionine plus cystine deficiency had the least and the most effect on body weight change among the essential amino acids, respectively.

OUSTERHOUT ${ }^{14)}$ showed that chicks fed diets lacking isoleucine lost weight rapidly and caused early death to the same extent as the birds fed methionine plus cystine-free diet did. OKumura and $\mathrm{MORI}^{16)}$ reported that in chicks fed the diets $50 \%$ deficient in single essential amino acid, body weight change and nitrogen retention was reduced most severely by deficiency of isoleucine. Comparing the severity of isoleucine deficiency, the effects were widely different in young and adult chickens. In the present experiment isoleucine deficiency had the medium effect in adult roosters, however in chicks it had the severest one. The difference of isoleucine deficiency response could not be explained, but isoleucine requirement for the growth and the maintenance might give an answer. From these results, it was shown that equal single deficiencies of essential amino acids had different effects on nitrogen balance and body weight change of the adult roosters and all amino acids tested could be roughly divided into three groups with respect to the degree of effect of deficiency; the first group which had the least effect, lysine, histidine and leucine; the second group which had medium effect, tryptothan, glycine, phenylalanine and isoleucine; the third group which had the severest effect, threonine, arginine and methionine. 


\section{Summary}

Diets completely devoid of single essential amino acid were fed to adult roosters for 7 days to investigate the effect on nitrogen balance and body weight change. Depending upon the kind of amino acid deprived from the diet the effects were different and the existence of the nutritional specificity of essential amino acid was confirmed. Among the essential amino acids tested, lysine, histidine and leucine had the least effect and threonine, arginine and methionine had the severest one. All other amino acids tested, tryptophan, glycine, phenylalanine and isoleucine, had medium effect of deficiency.

\section{References}

1) Bцоск, R. J. and H. H. Miтchell (1946) The correlation of the amino acid composition of proteins with their nutritive value: Nutr. Abst. Rev., 16: 249-278.

2) Ashida, K. and A. Yoshida (1972) Nutritional specificities of essential amino acids and their relationship to evaluation of the nutritional quality of dietary proteins: Proceedings of 9th International Congress of Nutrition, Mexico. 3: 407-424, Washington, D. C.

3) Leveille, G. A. and H. Fisher (1959) Amino acid requirement for maintenance in the adult rooster. II. The requirements for glutamic acid, histidine, lysine and arginine: J. Nutr., 69: 289-294.

4) Ishibashi, T. (1972) Maintenance of positive nitrogen balance in the adult rooster on the phenylalanine-free diet: Jpn. J. Zootech. Sci., 43: 463-469.

5) Okumura, J., H. Tanaka and T. Muramatsu (1978) Utilization of dietary urea by chicks: Japan Poultry Sci., 15: 163-169.

6) Nesheim, M. C., J. D. Garlich and D. T. Hopkins (1962) Studies on the effect of raw soybean meal on fat absorption in young chicks: J. Nutr., 78: 89-94.

7) Duncan, D. B. (1955) Multiple range and Multiple F tests: Biometrics, 11: 1-42.

8) Ishibashi, T. (1973) Amino acid requirements for maintenance of the adult rooster: Jpn. J. Zootech. Sci., 44: 39-49.

9) Ishibashi, T. and M. Kametaka (1974) Effect of the phenylalanine-free diet on the nitrogen balance, body weight and plasma free amino acid levels in the domestic fowl at various ages: Agr. Biol. Chem., 38: 241-245.

10) Okumura, J. and T. Muramatsu (1978) The nitrogen sparing action of amino acids in chicks fed a protein-free diet: Jpn. J. Zootech. Sci., 49: 345-350.

11) Yokogoshi, H. and A. Yoshida (1974) Effect of supplementation of methionine and threonine to a nonprotein diet on the protein catabolism of rats: Nutr. Rep. Int., 10: 371-380.

12) Leveille, G. A. and H. Fisher (1960) Amino acid requirement for maintenance in the adult rooster. III. The requirements for leucine, isoleucine, valine and threonine, with reference also to the utilization of the D-isomers of valine, threonine and isoleucine: J. Nutr., 70: 135-140.

13) Leveille, G. A., R. Shapiro and H. Fisher (1960) Amino acid requirement for maintenance in the adult rooster. IV. The requirements for methionine, cystine, phenylalanine, tyrosine and tryptophan; The adequacy of the determined requirements: J. Nutr., 72: 8-15.

14) Ousterhout, L. E. (1960) Survival time and biochemical changes in chicks fed diets lacking different amino acids: J. Nutr., 70: 226-234.

15) Said, A.K. and D. M. Hegsted (1970) Response of adult rats to low dietary levels of essential amino acids: J. Nutr., 100: 1363-1376.

16) Okumura, J. and S. Mori (1979) Effect of deficiencies of single essential amino acids on nitrogen and energy utilization in chicks: Br. Poult. Sci., 20: 421-429. 


\title{
単一必須アミノ酸完全欠乏飼料を給与した成鵎雄の 窒素出納及び体重の変化
}

\author{
奥村純市 ${ }^{11}$ ・中広義雄 ${ }^{2}$ ・ 木野勝敏 ${ }^{1}$
}

\author{
1) 名古屋大学 名古屋市 464 \\ 2) 香川大学: 香川県 761-07
}

ニワトリに必須アミノ酸を単独で完全に除いた飼料を 給与すると, 負の窒素出納, 体重の減少を示すが, これ ら指標への影響の程度が欠乏させるアミ，酸の種類によ りどのよらに変化するかを調查した。

供試鷄には白色レグホーン種成䳕雄を用い, 各飼料区 6 反復となるよら分配した後, 代謝ヶージ内で 7 日間単 飼した. 実験は 2 回に分けて行ない, 成䳕雄の各必須了 ミ，酸要求量を充たす $5.8 \%$ ア、，酸混合物を含んだ完 全餇料から，具験 1 では，アルギニン，ヒスチジン，リ ジン, トリソトファン, スレオニン, イソロイシン, ィ チォニンを, 尖験 2 では, ロイシン，つェニルアラニン, メチオニンをそれぞれ単独で完全に取り除いた飼料を各 羽 $30 \mathrm{~g} / \mathrm{kg}$ 体重/日の割合で与え, 実験後半 3 日間の军 素出納及び期間中の体重の变化を測定した。

窒素出納, 体重の変化への必須アミ, 酸欠乏の影響は
欠乏させるアミノ酸の種類によって様々であり,リジ ン, ヒスチジンは必須アミノ酸の中でもその欠乏の影響 は最も弱く，これに対しメチオニンの欠乏は最強く， 全くアミノ酸を含まない飼料を給与した群と比較して も，ほぼ等しい体重減少とより低い窒素出納を示した。 同程度の欠乏であっても欠乏させるアミノ酸の種類によ りその影響が異なるといらアミノ酸の栄養特異性の存在 が確認され，また必須アミ，酸を完全欠巨の影響の程度

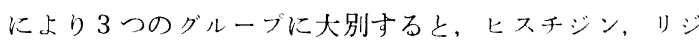
ン,ロイシンは弱いグルーフに, トリフトファン, フェ ニルアッシン, グリシン, イソロイシンは中程度のグル ーブに,スレオニン,アルギニン, ィチオニンは強いク ループに分けられた。

(家禽会誌，22，17～22，1985） 